\title{
PENDIDIKAN MULTIKULTURAL INTERRELIGIUS: UPAYA MENYEMAI PERDAMAIAN DALAM HETEROGENITAS AGAMA PERSPEKTIF INDONESIA
}

\author{
Mahathir Muhammad Iqbal \\ Lembaga Kajian dan Pengembangan Sumberdaya Manusia Nahdlatul Ulama \\ (Lakpesdam) PCNU Kota Malang \\ Email: Iqbalz_mm@yahoo.com
}

\begin{abstract}
This article was written with the purpose to obtain a picture of interreligious conception of multicultural education as an attempt to create peace in the livelihood of the Indonesian nation that is multicultural. Conception of multicultural education were developed through in-depth and intensive literature studies. The author emphasizes the idea of multireligious and interreligious education models, not monoreligius, so that each element in different nations and religious beliefs in this country will show the inclusive character including attitude of brotherbood, mutual tolerance for differences, respect for differences, and to avoid a culture of violence.
\end{abstract}

Keywords: multicultural, interreligious education, tolerance

\begin{abstract}
Abstrak
Artikel ini ditulis dengan tujuan untuk memperoleh gambaran tentang konsepsi pendidikan multikultural interreligius sebagai sebuah upaya untuk menciptakan perdamaian dalam peri kehidupan bangsa Indonesia yang multikultural. Konsepsi pendidikan multikultural tersebut dikembangkan melalui kajian kepustakaan secara mendalam dan intensif. Penulis menekankan gagasan tentang pendidikan agama model multireligius dan interreligious, bukan monoreligius, sehingga setiap elemen bangsa yang berbeda keyakinan dan agama di negeri ini akan menampilkan karakter yang inklusif termasuk sikap persaudaraan, saling toleransi terhadap perbedaan, saling menghormati terhadap perbedaan, serta terhindar dari budaya kekerasan.
\end{abstract}

Kata kunci: multikultural, pendidikan interreligius, toleransi

\section{A. Pendahuluan}

Indonesia adalah bangsa yang khas dan unik. Menurut Clifford Geertz, Indonesia merupakan negeri tempat semua arus kultural sepanjang tiga milenia mengalir berurutan memasuki Nusantara dari India, Cina, Timur Tengah, dan Eropa yang terwakili di tempat-tempat tertentu. Seperti di Bali terdapat komunitas agama Hindhu, pemukiman Cina terlihat di Jakarta, Semarang dan Surabaya, pusat-pusat muslim di Aceh, Makasar atau dataran tinggi Padang, di daerah-daerah Minahasa dan Ambon yang Calvinis atau daerah-daerah Flores yang Katolik. ${ }^{1}$

Selain memaparkan fakta historis kultural seperti disebut di atas, Geertz juga menunjukkan fakta tentang situasi masyarakat Indonesia

\footnotetext{
1 Taufiq Rohman Dhohiri, dkk, Sosiologi 2: Suatu Kajian Kehidupan Masyarakat. (Jakarta: Ghalia Indonesia), 2006, h. 123.
}

yang memiliki rentang struktur sosial yang lebar, seperti sistem-sistem Melayu Polinesia di pedalaman Kalimantan dan Sulawesi, ibu kotaibu kota provinsi yang kumuh dan kota-kota kecil di Jawa dan di luar Jawa, kota-kota metropolitan seperti Medan, Surabaya dan Makasar, dan keanekaragaman bentuk perekonomian, sistemsistem stratifikasi atau aturan kekerabatan juga melimpah ruah.

Nurcholish Madjid mendefinisikan budaya Indonesia atau keindonesiaan, tidak lain adalah hasil interaksi yang kaya (resourcefull) dan dinamis antarpelaku budaya yang beranekaragam itu dalam suatu melting pot yang efektif. ${ }^{2}$ Singkat kata, Indonesia adalah bangsa majemuk paripurna

2 Nurcholish Madjid, "Asas-Asas Pluralisme dan Toleransi Dalam Masyarakat Madani, dalam Abuddin Nata, dkk (ed), Problematika Politik Islam di Indonesia, Jakarta: UIN Jakarta Press, 2002, h. 3. 
(par excellence). ${ }^{3}$

Rupert Emerson, dalam Harold R. Isaacs, Idols of the Tribe: Group Identity and Political Change, pernah mengatakan bahwa bangsa adalah masyarakat luas yang apabila dalam keadaan krisis, secara efektif memimpin loyalitas orang-orang, yang untuk tujuan sekarang merupakan akhiran yang efektif dari perjalan manusia sebagai makhluk sosial (bomo socius) dan tujuan akhir dari solidaritas yang berlaku di antara manusia. Bangsa harus dilihat sebagai masyarakat yang membuat pendekatan yang paling dekat untuk merangkul semua aspek kehidupan, keluarga, suku-suku, dan kelompok keagamaan.

Sejatinya ada tiga kecenderungan yang sering dihadapi masyarakat multikultural, yakni: (1) mengidap potensi konflik yang kronis di dalam hubungan-hubungan antarkelompok, (2) pelaku konflik melihat sebagai all out war (perang habis-habisan), dan (3) proses integrasi sosial lebih banyak terjadi melalui dominasi atas suatu kelompok oleh kelompok lain. Potensi konflik dalam masyarakat majemuk ini menjadi sesuatu yang sudah tidak dapat dipungkiri lagi bahwa di masa lalu kerukunan umat beragama harus dibayar dengan amat mahal, seperti meledaknya konflik antaragama di sejumlah daerah. Karena itulah, tantangan terbesar dari masyarakat majemuk adalah rapuhnya ikatan kebersamaan akibat perbedaan agama yang mudah menyulut konflik agama jika tidak berhasil dikelola dengan baik. Konflik agama selalu menjadi tantangan yang sangat serius bagi bangsa Indonesia yang majemuk. Dengan kata lain, kemajemukan sering menjadi sumber ketegangan sosial. Karena, kemajemukan sebagai sumber daya masyarakat yang paling pokok untuk mewujudkan masyarakat plural dikikis habis oleh kepalsuan dan manipulasi.

Adalah fakta sejarah bahwa masyarakat Indonesia hidup dalam keadaan pluralistik, beragam, baik secara natural (jenis kelamin, ras dan etnis) maupun secara kultural (bahasa, struktur sosial, nilai-nilai yang dianut, dan tradisi keagamaan). Indonesia adalah bangsa yang majemuk yang diperlihatkan dari banyaknya agama, suku, dan ras. Kemajemukan di Indonesia

3 Yudi Latif, NEGARA PARIPURNA: Historisitas, Rasionalitas, dan Aktualitas Pancasila. Jakarta: PT. Gramedia), 2007, h. 252. telah lama hadir sebagai realitas empirik yang tak terbantahkan. Indonesia kemudian dikenal sebagai bangsa dengan sebutan "mega cultural diversity" karena Indonesia terdapat tidak kurang dari 250 kelompok etnis dengan lebih dari 500 jenis ragam bahasa yang berbeda. ${ }^{4}$

Dalam perspektif Indonesia, pluralitas kehidupan ini merupakan rantai kesinambungan dari tradisi megalitik di masa prasejarah. Keragaman ini, menurut sementara arkeolog, terwujud dalam tiga aspek kehidupan, yakni teknologi, organisasi sosial, dan religi. Dalam hal teknologi, tradisi megalitik telah menghasilkan alat batu yang bentuknya beragam. Dalam organisasi sosial, keragaman ditandai oleh pembagian kerja, yang pada gilirannya memunculkan kelompok-kelompok fungsional serta pola hubungan yang bersifat struktural, vertikal, dan horizontal. Begitu juga dalam agama, terdapat pola keragaman ritualitas yang bertumpu pada kepercayaan terhadap arwah nenek moyang. Unsur religi ini merupakan aspek yang paling dominan dan sangat berpengaruh dalam kehidupan bermasyarakat pada waktu itu.

Dewasa ini, ciri pluralistik dalam masyarakat bukan saja menjadi realitas yang tak terbantahkan, tetapi juga menjadi problematika tersendiri. Pluralitas menjadi isu penting seiring dengan semakin menguatnya berbagai tuntutan dari komunitas-komunitas masyarakat atau entitas budaya, terutama mereka yang minoritas dan pinggiran, agar dalam kerangka hegemoni universalisme dan keragaman ini eksistensinya diakui.

Pluralitas kehidupan memiliki dua aspek yang hadir secara bersama-sama bagai dua sisi mata uang yang tak terpisahkan. Pada satu sisi, secara fungsional pluralitas merupakan "rahmat", sebagai khasanah sosial budaya yang memainkan peran-peran tertentu yang dianggap positif bagi masyarakat. Manusia juga dapat menumbuhkembangkan nilai-nilai dan peradaban bersama demi mencapai sebuah idealitas kehidupan. Kendati di dalamnya terdapat kemungkinan terjadi bentrokan,

4 Jika setiap suku bangsa dicirikan oleh bahasa etnik yang mereka pakai, para ahli lingustik mencatat lebih dari 1500 bahasa etnik di Indonesia. Akan tetapi kenyataannya, dua atau lebih suku bangsa yang berbeda bisa menggunakan satu bahasa yang sama, sehingga jumlah suku bangsa di Indonesia lebih banyak dari jumlah bahasa etnik. Meskipun demikian, pada umumnya, suku bangsa di Indonesia dicirikan dan dinamakan dengan nama bahasa etniknya, untuk uraian lebih mendalam, lihat Zulyani Hidayah, Ensiklopedia Suku Bangsa di Indonesia. Jakarta: LP3ES. 1997. 
namun bentrokan itu bisa diupayakan agar tidak merusak tatanan sosial. Juga karenanya, masyarakat yang hidup di dalamnya mesti dibekali dengan elan (semangat) kesetiaan, solidaritas, dan toleransi.

Tetapi pluralitas, pada sisi yang lain, juga merupakan tantangan dan persoalan yang pada saat-saat tertentu menghantui masyarakat. Di sana-sini pluralitas sering manjadi "prakondisi", kalau bukan sebagai sumber, bagi instabilitas, konflik, dan disintegrasi sosial, kekerasan, bahkan pembunuhan massal. Meski demikian, menurut perspektif para panganut teori konflik, keadaan musykil yang menyertai pluralitas tidak lain adalah proses sosial yang terpaksa harus ditempuh manusia demi pencapaian-pencapaian tertentu dalam kehidupannya. Senegatif-negatifnya pluralitas itu tentu memiliki nilai positif bagi, katakanlah, proyek revolusi (progresivitas) sosial. ${ }^{5}$

Pendidikan multikultural sangat penting dan sangat dibutuhkan oleh bangsa yang majemuk dalam hal agama. Jika toleransi beragama tidak ditegakkan, bangsa atau negara tersebut akan menghadapi berbagai konflik antarpemeluk masing-masing agama dan dapat menyebabkan disintegrasi nasional. Untuk memberi perhatian khusus kepada masalah pluralitas beragama, harus diupayakan pemahaman yang benar dan ditemukan cara untuk menciptakan kerukunan tersebut.

\section{B. Justifikasi Teologis}

Pluralitas beragama dalam perspektif justifikasi teologis, terutama dalam agama Islam, seharusnya merupakan suatu nilai yang terlembagakan dalam masyarakat. Islam mengajarkan bahwa agama Tuhan adalah universal karena Tuhan telah mengutus RasulNya kepada setiap umat manusia. ${ }^{6}$ Selain itu, ajaran Islam juga mengajarkan tentang pandangan tentang kesatuan kenabian (nubuwwah) dan umat yang percaya kepada Tuhan. ${ }^{7}$ Ditegaskan juga bahwa agama yang dibawa oleh Nabi Muhammad SAW (Islam) adalah kelanjutan langsung agama-agama yang

\footnotetext{
5 Aba Du Wahid, Ahmad Wahib: Pergulatan Doktrin dan Realitas Sosial, Yogyakarta: Resist Book, 2004.

6 Q.S. An-Nahl (16): 36.

7 Q.S. Al-Anbiya' (21): 92
}

dibawa nabi-nabi sebelumnya..$^{8}$ Oleh karena itu, Islam memerintahkan umatnya untuk menjaga hubungan baik dengan para pemeluk agama lain, khususnya para penganut kitab suci (Ahli Kitab). ${ }^{9}$

Prinsip-prinsip Islam seperti yang terbubuh dalam ayat-ayat al-Quran di atas membawa konsekuensi adanya larangan untuk memaksakan agama. ${ }^{10}$ Ayat ini, menurut Ibn alQayyim al-Jauzi, seperti dikutip oleh Nurcholish Madjid, diturunkan karena ada anak-anak kaum anshar di Madinah yang tidak mau mengikuti jejak orang tua mereka untuk memeluk Islam dan memilih agama Yahudi yang sudah mereka kenal, tetapi kemudian orang tua mereka ingin memaksa mereka memeluk agama Islam. ${ }^{11} \mathrm{Hal}$ ini mendapat penegasan firman Allah: "Dan jika seandainya Tuhanmu menghendaki, maka pastilah beriman semua orang di bumi, tanpa kecuali. Apakah engkau (Muhammad) akan memaksa umat manusia sebingga mereka beriman semua?"12 Pendirian ini perlu dikemukakan karena sampai sekarang masih dirasakan kekurang-percayaan kepada prinsip ini dari berbagai kalangan.

Dalam kajian sejarah agama Islam, pluralitas mempunyai akar historis yang kuat. Semua sarjana mengetahui dan mengakui bahwa tindakan Nabi SAW dalam mewujudkan masyarakat Madinah, yaitu dengan menetapkan dokumen perjanjian yang disebut Mitsaq alMadinab (Piagam Madinah), yang di kalangan para sarjana Barat dikenal sebagai Konstitusi Madinah. Inilah dokumen politik pertama dalam sejarah umat manusia, yang meletakkan dasar-dasar pluralisme dan toleransi. Dalam piagam itu ditetapkan adanya pengakuan kepada semua penduduk Madinah, tanpa memandang perbedaan agama dan suku, sebagai anggota umat yang tunggal (ummatan wabidah), dengan hak-hak dan kewajiban-kewajiban yang sama. ${ }^{13}$

Di antara aspek pluralitas yang tinggi potensialitas peran positif-negatifnya adalah pluralitas keagamaan. Hal ini tidak terlepas

\footnotetext{
8 Q.S. Al-Syura (42): 13

Q.S. Al-'Ankabut (29): 46.

Q.S. Al-Baqarah (2): 256.

Nurcholish Madjid Madjid, “Asas-Asas Pluralisme dan Toleransi Dalam Masyarakat Madani, dalam Abuddin Nata, dkk (ed), Problematika Politik Islam di Indonesia. Jakarta: UIN Jakarta Press, 2002, h. 110.

12 Q.S. Yunus (10): 99.

13 Piagam Madinah itu telah diterjemahkan oleh A. Guillaume, dalam buku the life of Muhammad (terj. Kitab Ibn ishaq, Sirat Rasul Allah), Karachi, Oxford University Press, 1980, h. 231-233.
} 
dari keberadaan agama yang memiliki fungsi multi-faces. Agama bisa berperan sebagai faktor kohesi sosial di mana manusia pemeluknya bisa menemukan kedamaian dan kebahagiaan, individu dan masyarakat, di dalamnya. Tetapi di saat lain agama bisa juga sebagai faktor konflik dan disintegrasi. Dengan agama orang bisa meledakkan suatu revolusi sosial yang berwatak kekerasan dan intoleran. Dengan agama pula suatu masyarakat bisa bangkit menafikan, melawan, dan membasmi kelompok masyarakat lainnya.

Agama di Indonesia memegang peranan penting dalam kehidupan masyarakat. Hal ini dinyatakan dalam ideologi bangsa Indonesia, Pancasila: "KeTuhanan Yang Maha Esa". Sejumlah agama di Indonesia berpengaruh secara kolektif terhadap politik, ekonomi, dan budaya. Pada tahun 2010, kira-kira $85,1 \%$ dari 240.271 .522 penduduk Indonesia adalah pemeluk Islam, 9,2\% Protestan, 3,5\% Katolik, 1,8\% Hindu, dan 0,4\% Budha. ${ }^{14}$

Dalam UUD 1945 dinyatakan bahwa "tiaptiap penduduk diberikan kebebasan untuk memilih dan mempraktikkan kepercayaannya" dan "menjamin semuanya akan kebebasan untuk menyembah, menurut agama atau kepercayaannya". Pemerintah, bagaimanapun, secara resmi hanya mengakui enam agama, yakni Islam, Protestan, Katolik, Hindu, Budha dan Khonghucu. Meskipun keenam agama ini yang mendapatkan perhatian negara, tetapi para penganut agama lainnya, seperti Baha'i, Sinto, Yahudi, dan agama pribumi yang diwarisi oleh keyakinan para leluhur diberikan kebebasan untuk dipeluk dan diyakini oleh masyarakat.

\section{Fakta Kerukunan Umat Beragama di Indonesia}

Kesadaran akan masyarakat yang plural tidak serta merta membekali masyarakat dengan sikap arif dalam menyikapinya. Sikap arif terhadap dua sisi pluralitas ini terkadang membingungkan. Ini karena, pertama, orang tidak memahami persis apa sisi positif dan negatif dari fenomena ini, sehingga tidak bisa memutuskan kapan dimanfaatkan dan untuk keperluan apa, atau kapan dihindari dan bagaimana. Kedua, dibalik pluralitas ini bisa termuat faktor eksternal berupa kepentingankepentingan suatu pihak yang memanfaatkannya demi capaian-capaian tertentu. Politik misalnya, sebagai kegiatan pemanfaatan kondisi yang ada dalam masyarakat untuk mencapai kepentingan, adalah faktor yang paling dominan yang menyertai munculnya pelbagai akses negatif dari pluralitas masyarakat.

Tak heran jika bangsa Indonesia pernah mengalamai konflik di Ambon dan Poso. Konflik massif di Ambon dan Poso tampaknya bukan akhir dari konflik. Konflik baru masih bermunculan dalam skala kecil, tetapi meluas ke banyak daerah dalam bentuk konflik pendirian rumah ibadah. Bekasi, Bogor, Depok, Kupang, Denpasar, Kota Padang, Makassar, dan sejumlah daerah lainnya menunjukkan eskalasi konflik kecil dalam soal pendirian rumah ibadah. Masyarakat masih begitu sensitif terhadap halhal yang dianggap menyinggung keyakinannya, terutama dalam pendirian rumah ibadah dan penyiaran agama. Ini berarti tingkat potensi laten terjadinya konflik bernuansa agama di Indonesia masih cukup tinggi.

Mengutip perrnyataan Ketua Umum PBNU K.H. Said Aqil Siradj, kita kerap disuguhi adegan penggerebekan dan penggusuran. Kisruh pembangunan gereja dan juga konflik internal agama masih bergejolak dengan saling menyesatkan. Agaknya, ada sesuatu yang "tidak beres". 15

Berdasar data yang dirilis oleh Litbang "Kompas" sentimen keagamaan, termasuk radikalisme dan melemahnya toleransi masih menjadi hal yang dinilai sebagai ancaman bagi masa depan kebangsaan Indonesia. ${ }^{16}$

\footnotetext{
15 Said Aqil Siradj, “Mengurai kekusutan Keberagamaan”, Jawa Pos. 26 Januari 2012, h 4.

16 Pengumpulan pendapat melalui telepon ini diselenggarakan Litbang Kompas pada 16-18 Mei 2012. Sebanyak 869 responden berusia minimal 17 tahun dipilih secara acak menggunakan metode pencuplikan sistematis dari buku telepon terbaru. Responden berdomisili di 12 Kota di Indonesia. Jumlah wilayah responden di setiap wilayah ditentukan secara proporsional. Menggunakan metode ini tingkat kepercayaan $95 \%$, nirpencuplikan penelitian $+3,3 \%$. Meskipun demikian, kesalahan diluar pencuplikan dimungkinkan terjadi. Hasil jajak pendapat ini tidak dimaksudkan untuk mewakili pendapat seluruh masyarakat Indonesia.
} 
Gambar 1: Ancaman bagi kebangsaan Indonesia

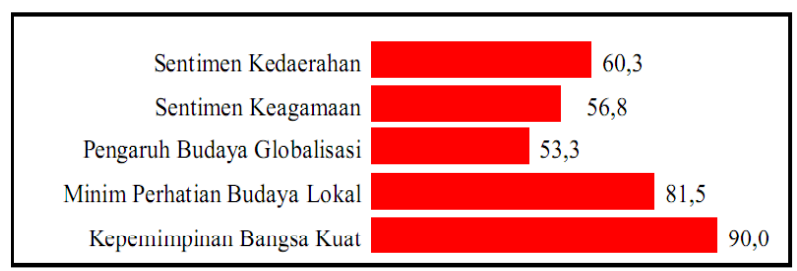

Sumber: Litbang "Kompas"

Senada dengan data yang dilansir oleh Litbang Kompas di atas, Lingkaran Survei Indonesia dan Yayasan Denny J.A. mengungkap hasil survei mengejutkan mengenai kehidupan antar-umat beragama di Indonesia. Survei itu mengatakan mayoritas masyarakat di Indonesia merasa tidak nyaman jika hidup berdampingan, dan bertetangga dengan yang berbeda, baik itu beda agama juga beda orientasi seksual. Sebanyak 15,1 persen responden mengaku tidak nyaman hidup berdampingan dengan tetangga berbeda agama. Angka intoleran terhadap aliran yang dianggap sesat lebih tinggi lagi. Sebanyak 41,8 persen mengaku tak nyaman bertetangga dengan aliran Syiah. Sedangkan 46,6 persen mengatakan tak nyaman dengan Ahmadiyah. ${ }^{17}$

Pada tahun 2013 (periode Januari-Juni), sebuah organisasi hak asasi manusia yang menaruh perhatian pada pemajuan kondisi hak asasi manusia di Indonesia bernama SETARA Institute mencatat 122 peristiwa pelanggaran kebebasan beragama/berkeyakinan yang mengandung 160 bentuk tindakan, yang menyebar di 16 provinsi. Separuhnya terjadi di Jawa Barat (61 peristiwa), pelanggaran tertinggi berikutnya yaitu, Jawa Timur (18 peristiwa), dan DKI Jakarta (10 peristiwa).

Ironisnya, dari 160 bentuk tindakan pelanggaran kebebasan beragama berkeyakinan, terdapat 70 tindakan negara yang melibatkan para penyelenggara negara sebagai aktor. Dari 70 tindakan negara tersebut, 58 tindakan merupakan tindakan aktif (by commission), termasuk 11 tindakan penyegelan tempat ibadah dan 8 tindakan diskriminasi. Sementara 12 tindakan merupakan tindakan pembiaran (by omission). Termasuk dalam tindakan aktif negara adalah pernyataan-pernyataan pejabat publik yang provokatif dan mengundang terjadinya

17 http://indonesia.faithfreedom.org/forum/survei-lsi-masyrakatindonesia-semakin-tidak-toleran-t50247/. (Diakses 4 April 2014). kekerasan (condoning).

Institusi negara yang paling banyak melakukan pelanggaran adalah Kepolisian RI sebanyak 23 tindakan, disusul unsur pemerintah daerah di semua tingkatan pemerintah provinsi, pemerintah kabupaten/kota dengan 20 tindakan, serta Satuan Polisi Pamong Praja (Satpol PP) dengan 14 tindakan. Selebihnya adalah institusiinstitusi dengan jumlah tindakan di bawah 8 tindakan. Dari 160 bentuk tindakan pelanggaran kebebasan beragama dan keyakinan terhadap Tuhan Yang Maha Esa, terdapat 90 tindakan yang dilakukan oleh warga negara. Tindakan yang paling menonjol adalah dalam bentuk intoleransi sebanyak 19 tindakan, 9 tindakan berbagai motif pengancaman, dan 6 tindakan diskriminasi.

Pelaku tindakan pelanggaran pada kategori ini adalah individu warga negara maupun individu-individu yang tergabung dalam organisasi masyarakat. Kelompok yang paling banyak melakukan pelanggaran secara berturut-turut adalah: kelompok warga sebanyak 35 tindakan, Front Pembela Islam (FPI) sebanyak 10 tindakan, dan Forum Umat Islam (FUI) sebanyak 6 tindakan. Tingginya jumlah kelompok warga yang menjadi aktor pelanggaran menjadi indikasi bahwa intoleransi telah menyebar ke berbagai komunitas warga. Pelanggaran kebebasan beragama dan berkeyakinan terhadap Tuhan Yang Maha Esa periode Januari-Juni 2013 paling banyak menimpa Jemaat Ahmadiyah (46 peristiwa), umat Kristen (30 peristiwa), Syiah (12 peristiwa), serta umat dan aliran keagamaan Islam (13 peristiwa).

Masih serupa dengan tahun-tahun sebelumnya, dominasi peristiwa pelanggaran kebebasan beragama atau berkeyakinan terhadap Tuhan Yang Maha Esa adalah berhubungan dengan kriminalisasi keyakinan atau penyesatan terhadap paham atau aliran keagamaan minoritas, pendirian tempat ibadah, diskriminasi yang berlanjut terhadap Ahmadiyah, dan pembiaran institusi kepolisian dalam menangani kasus-kasus kekerasan atas nama agama. Sejumlah kasus yang menyulut eskalasi peristiwa pelanggaran kebebasan beragama $\mathrm{d}$ atau berkeyakinan terhadap Tuhan Yang Maha Esa pada periode ini adalah kasus 
Jemaat Ahmadiyah Jawa Barat, Syiah Sampang Madura, kasus pembongkaran Gereja Setu Bekasi, serta kasus pelemparan bom molotov secara berantai di Sulawesi Selatan. Contoh lain, belum lama ini, sebagian masyarakat Kelurahan Lenteng Agung, Jakarta Selatan, menolak kehadiran lurah yang seorang wanita bernama Susan Jasmine Zulkifli hanya dikarenakan yang bersangkutan beragama Kristen Protestan. ${ }^{18}$

Menyimak data dan fakta, serta peristiwa pelanggaran kebebasan beragama atau berkeyakinan terhadap Tuhan Yang Maha Esa di atas, tampak jelas bahwa intoleransi yang direfleksikan dalam bentuk kekerasan fisik maupun psikis terus menyebar ke berbagai institusi dan kelompok, selain aktor yang masuk dalam kelompok ormas. Jika eskalasi kekerasan terus dibiarkan tanpa penanganan sistemik dan terintegrasi, Indonesia akan berada satu kelas bersama Nigeria dan Pakistan dalam hal tingkat indeks intoleransi beragama, sebagaimana analisis seorang peneliti dari Christian Solidarity Worldwide yang berbasis di London. ${ }^{19}$

\section{Level Mikro: Tantangan Ke-Indonesia- an}

Pada dasarnya, setiap agama mengajarkan perdamaian, kebersamaan, sekaligus menebar misi kemaslahatan bagi lingkungan di sekitarnya. Namun dalam tataran sosiologis, wajah agama tidak seideal seperti yang diharapkan dalam kerangka normatif tersebut. Kerapkali wajah agama tampak bopeng, tercoreng dan ternoda dalam kecamuk konflik sosial, budaya, ekonomi, dan politik. Demikian itu sebenarnya bukan kesalahan ajaran agama itu sendiri, namun lebih diakibatkan oleh human error, yakni sebagian para pemeluknya yang kadang kala menafsirkan ajaran teologis normatif secara serampangan. Bisa juga karena kepentingan politik atau ekonomi sebagian umat beragama yang terlalu berlebihan, sehingga mengalahkan kepentingan agama. Atau mungkin juga karena kesalahan sistem negara, yang menjadikan politik sebagai panglima dalam segala urusan bangsa, sehingga politik dinyatakan sebagai cara paling rasional untuk menangani segala persoalan masyarakat,

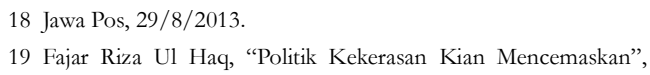

termasuk persoalan agama. ${ }^{20}$

Senada dengan hal diatas, Nur Syam, mantan rektor IAIN Sunan Ampel, dalam bukunya yang berjudul "Transisi Pembaruan Dialektika Islam, Politik, dan Pendidikan" menuliskan bahwa agama mempunyai dua wajah yang berbeda. Ketika agama tampil dengan wajah yang teduh, damai, dan bersahabat, agama bisa memperkuat solidaritas sosial (social order). Dengan kata lain, agama merupakan sarana mempererat relasi antarkomunitas, bahkan lintas agama. Tetapi, agama juga mempunyai potensi menimbulkan konflik sosial (social conflict). Hal itu disebabkan karena setiap agama memiliki klaim kebenaran (truth claim) sebagai identitas, aktualisasi, dan eksistensi. Ketika klaim kebenaran tampil demikian kuat sebagai manifestasi harga diri, kesakralan bisa menegangkan bahkan menakutkan. Dalam posisi inilah sumber konflik terjadi karena benturan kian keras.

Menurut Abdul A'la, rektor IAIN Sunan Ampel Surabaya, ketidakmampuan teologi menangkap perkembangan realitas kehidupan bermasyarakat telah mengakibatkan agama bersifat eksklusif dan defensif. Itu menjadi salah satu faktor ketidakmampuan agama menjadi landasan bagi terciptanya kehidupan beragama yang rukun dan damai. Akibatnya, kepentingan masyarakat sering terkoyak oleh sikap arogansi merasa benar sendiri (truth claim) dari sekelompok orang atau sejumlah orang yang menempatkan target ekslusifnya sebagai kepentingan istimewa dan absolut yang tidak bisa digeser oleh kepentingan dalam skala yang lebih besar, yaitu kepentingan masyarakat.

Kondisi ini diperparah oleh mereka yang berada di puncak piramida kekuasaan yang gagal memimpin (mengendalikan), mendidik, dan menghumanisasikan diri karena kita masih menjatuhkan egoisme sektoral, kelompok, dan merasa paling ber-Tuhan atau melegalitaskan klaim "surgawi" tanpa memberi ruang bagi yang lain untuk berbeda dan berdemokrasi secara beradab.

Hal inilah rupanya yang membedakan kita dengan negara-negara yang kultur demokrasinya sudah mapan. Demokrasi mereka tampaknya telah sampai pada suatu taraf, di mana variabel

20 Lan Fang, "Kekerasan; Darimana-Oleh Siapa?", Jawa Pos, 26 maret 2011, h. 4. 
primodial seperti ras, kesukuan dan keagamaan tidak sangat berperan, dan rasionalitas menjadi pertimbangan utama. Kenyataan ini mengurangi konflik-konflik horizontal dan memudahkan mereka dalam mengambil keputusankeputusan bersama. Yang kini sedang terjadi adalah para elite kekuasaan bahkan seringkali mematikan atau menghilangkan apa yang disebut "paradigma kekuasaan". Apa yang mereka lakukan dari hari ke hari mengakibatkan makin tercerabutnya dan punahnya komitmen persaudaraan kemanusiaan, sehingga mereka gigih saling menabur brutal, jegal, dan jagal.

Berangkat dari fakta ini, memang diperlukan kerja keras dan upaya yang serius dari semua pihak, baik pemerintah maupun masyarakat sipil (civil society) untuk menyebarkan inspirasi perdamaian, yaitu antara lain sebagai berikut. Pertama, perlu melakukan rekonstruksi budaya, mengubah budaya kekerasan dan intoleran menjadi budaya damai (culture of peace). Kedua, yang tak kalah penting, adalah dengan menerapkan pendidikan yang menggunakan pendekatan multikultural dan berpijak pada nilai-nilai Pancasila dan prinsip pluralisme. Memahami pluralisme tidak cukup hanya dengan sikap mengakui dan menerima kenyataan masyarakat yang majemuk, tapi harus disertai dengan sikap yang tulus untuk menerima kenyataan kemajemukan itu sebagai nilai positif.

\section{E. Gagasan Pemecahan: Pendidikan Multikulturalisme Berbasis Interreligius}

Pengajaran agama yang menggunakan model monoreligius harus diubah menjadi multireligius dan interreligius. Selain telah membuat orang "buta" tentang agama lain, model pengajaran monoreligius yang hanya mengajarkan agama sendiri cenderung membuat orang bersikap pasif terhadap keragaman, jika bukan malah menarik diri.

Pendidikan yang bersifat agama monoreligius identik dengan pendidikan yang monokultural. Monokultur (budaya tunggal) adalah bentuk kehidupan yang tunggal dan seragam. Alam tak suka akan budaya-budaya seragam (Pattrick J Deneen) karena budaya seperti ini sangat rentan terhadap virus atau hama. Kerusakan yang akan terjadi bersifat total dan serempak.

Pendidikan agama monoreligius akan rentan pula terhadap ideologi radikal. Biasanya pendidikan macam ini tak memiliki banyak variasi dalam memberikan ilustrasi yang lengkap dan holistik. Sebab, yang diutamakan adalah metode pembelajaran dan tes yang terstandardisasi: tidak membuat peserta didik menjadi manusia yang utuh, dengan pemahaman akan dunia secara holistik. Yang diberikan gambaran-gambaran sempit, cenderung hanya memuji diri sendiri, dan sebaliknya buta terhadap budaya pihak lain. Akibatnya, metode pembelajaran macam ini hanya memproduksi alumni yang tidak adaptif terhadap dunia yang berubah, bahkan berpotensi (menurut Deneen) menjadi suatu gerombolan terideologi tunggal yang mudah dimobilisasi. Padahal, pembentukan masyarakat yang plural adalah kebutuhan sosial mendasar. Sebab, di mana dan kapan pun akan terjadi petaka ketika sekumpulan orang yang besar bergerak ke arah yang sama, secara serempak, memperebutkan ruang, kesempatan, dan materi yang terbatas. Dalam keadaan seperti ini yang terjadi hanya desak-desakan, saling dorong, bahkan injakinjakan yang fatal. Malapraktik yang kuat yang menang akan berulang dengan sendirinya dalam situasi serba seragam dan serentak.

Alam dan manusia memang memerlukan kebinekaan nyata. Keberagaman ritual, tradisi, dan budaya dalam menghadirkan religiusitas perlu dilihat sebagai potensi, hikmah, atau subjek pembelajaran agama secara multikultural dan interkultural. Namun, untuk merealisasikan keinginan itu diperlukan komitmen bersama para pelaku dunia pendidikan yang sesungguhnya telah diatur dalam UUD 1945.

Pendidikan multireligius dan interreligius itu bukan hanya penting dan lebih mencerahkan, melainkan juga esensial dan fundamental bagi kesinambungan pergaulan sosio-kultural atau interaksi kemanusiaan. Daya hidup kesinambungan sosio-kultural hanya dapat berjalan secara baik, aman, indah, dan kreatif apabila masyarakat pendukungnya memberikan ruang dan toleransi bagi kemajemukan. ${ }^{21}$

Model-model monoreligius, multireligius,

21 M. Dwi Marianto, "Belajar Dari Alam dan Orang Desa", Kompas, 28 April 2014, h. 7. 
dan interreligius bukanlah kategori tingkatan di mana yang satu dengan sendirinya lebih unggul ketimbang yang lain. Masing-masing bisa menjadi model yang efektif menurut konteks yang berbeda. Model monoreligius, misalnya, adalah metode yang efektif untuk tujuan internalisasi dalam rangka meningkatkan kualitas iman, seperti yang dilakukan di pesantren atau seminari, di mana peserta didik memang mempunyai latar belakang agama yang seragam. Untuk menghindari kekhawatiran yang berlebihan, model monoreligius ini masih bisa diterapkan untuk sekolah umum, tetapi hanya di tingkat sekolah dasar.

Untuk sekolah menengah, model multireligiuslah yang semestinya digunakan. Melalui model ini, siswa berkesempatan mendapatkan pemahaman yang informatifdeskriptif tentang beberapa agama di sekitarnya. Dengan demikian, sejak dini siswa belajar mengapresiasi dan bersikap toleran terhadap para penganut dan warisan tradisi berbagai agama. Norma bersama dan sikap yang positif terhadap pluralitas hanya bisa dibentuk melalui proses yang panjang, antara lain melalui model pengajaran semacam ini.

Di perguruan tinggi umum model yang paling efektif adalah interreligius. Jika model multireligius menekankan pengajaran agamaagama yang bersifat deskriptif, informatif dan objektif tentang doktrin, ritual, dan sejarah agama tertentu, model interreligius bergerak lebih jauh dengan menekankan aspek dialog.

Meskipun telah berusaha seobyektif mungkin, seorang Muslim yang mempelajari agama Kristen, misalnya, mustahil bisa memahami agama itu sebagaimana yang dilakukan penganut Kristen. Memang bukan itu tujuannya. Oleh karena itu, selain kemampuan memperoleh informasi dan melakukan deskripsi berbagai agama secara memadai, dengan mempelajari agama-agama tersebut, yang lebih penting mahasiswa belajar melatih kemampuan melakukan dialog melalui proses dialektis berbicara dan mendengar, melihat dan dilihat, dengan menggunakan berbagai perspektif secara kritis.

Seorang mahasiswa Muslim yang mempelajari zaman kegelapan Kristen abad pertengahan, misalnya, tidak terutama bertujuan menemukan bukti-bukti realitas sejarah Kristen yang kelam kemudian dikontraskan dengan wajah ideal Islam. Melainkan, untuk memahami secara empiris bagaimana penggal sejarah itu terjadi dalam agama Kristen dan apakah hal yang sama juga terjadi dalam kurun dan bentuk yang mungkin berbeda dalam sejarah Islam dan mengapa. Banyak orang terampil memilih yang nyata dalam agama lain untuk dikontraskan dengan yang ideal dalam agama sendiri. Namun, apa hasilnya selain saling curiga, salah paham, dan kian berkobarnya rasa saling permusuhan?

Melalui proses dialog, seseorang bisa mendapat pemahaman kritis yang lebih baik serta sikap dan tindakan yang lebih tepat dan saling memperkaya dalam perjumpaan agama-agama. Dialog, sebagaimana dikemukakan Leonard Swidler, tentu akan "mengubah" pelakunya. Artinya, seseorang yang mempelajari agama lain—sebetulnya apa saja-akan mendapat pengaruh yang kemudian mengubah persepsi, sikap, dan tindakannya. Namun, jika dilihat secara positif, mengikuti John Cobb, perubahan itu justru mencerminkan pemahaman yang lebih diperkaya dan tercerahkan, baik tentang agama sendiri maupun agama orang lain sebab, sembari mempelajari "yang lain", melalui dialog itu seseorang sebetulnya terus-menerus diajak merefleksi dan mengenali kembali "diri sendiri" lebih intensif dari sejumlah perspektif.

Ini sekaligus menegaskan bahwa studi dan pengajaran agama model interreligius, dan juga multireligius, tak perlu menyeret orang kepada pendangkalan akidah atau relativisme agama, sebagaimana kadang dikhawatirkan. Sebaliknya, studi dan pengajaran agama model multireligius dan interreligius merupakan suatu metode yang efektif membentuk norma bersama dan sikap yang positif terhadap pluralitas agama sehingga perjumpaan agama bisa menjadi kesempatan saling memperkaya dan bekerja sama, guna mengoptimalkan potensi pribadi setiap pemeluk agama dalam pergaulan kemanusiaan.

\section{F. Penutup}

Akhirnya, kalau saja setiap elemen bangsa yang berbeda keyakinan dan agama di negeri ini benar-benar menunjukkan sikap persaudaraan inklusif, saling terbuka dalam menghormati perbedaan, tentu kekerasan yang mengorbankan 
nyawa antarpemeluk agama tidak perlu terjadi. Kedamaian dalam perbedaan bukan hal mustahil untuk dirasakan jika setiap elemen bangsa menyadari bahwa sebenarnya mereka saling membutuhkan.

Sudah saatnya semua elemen bangsa mendesain kehidupan keberagamaan yang berbasis inklusivitas dan humanitas (pemanusiaan manusia). Dalam konteks inilah pendidikan multikultural berbasis interreligius menjadi amat sangat strategis posisinya. Dengan pendidikan multikultural berbasis interreligius, maka diharapkan ada sebuah kesadaran diri dari pemeluk agama tertentu yang benar-benar mempelajari dengan sungguh-sungguh tradisi agama lain, tidak dalam semangat membuktikan kesalahan agama lain itu, tetapi untuk secara empatik menyelami tradisi itu dari dalam dan mengambil manfaat dari sana.

\section{Daftar Pustaka}

Abdhalla, Ulil Abshar. Menjadi Muslim Liberal. Jakarta: PT. Ikrar Mandiri Abadi. 2006.

Baidhawi, Zakiyuddin. Kredo Kebebasan Beragama. Jakarta: PSAP. 2005.

Dhohiri, Taufiq Rahman, dkk. Sosiologi 2: Suatu Kajian Kebidupan Masyarakat. Jakarta: Ghalia Indonesia. 2006.

Fang, Lan, "Kekerasan; Darimana-Oleh Siapa?", Jawa Pos, 26 maret 2011, hal. 4

Guillaume, A. the life of Muhammad. Terjemahan Ibn ishaq. Karachi: Oxford University Press. 1980.

Hanskung. Etik Global. Yogyakarta: Pustaka Pelajar. 1999.

Haq, Fajar Riza, Ul, "Politik Kekerasan Kian Mencemaskan”, Kompas, 21 Mei 2012. Hal. 7

Hidayah, Zulyani. Ensiklopedia Suku Bangsa di Indonesia. Jakarta: LP3ES. 1997.

Http://id.wikipedia.org/wiki/Agama_di_ Indonesia. (diakses 4 April 2014).

Http://indonesia.faithfreedom.org/forum/ survei-lsi-masyrakat-indonesia-semakintidak toleran-t50247/. (diakses 4 April 2014).
Isaacs, Harold R. Idols of the Tribe: Group Identity and Political Change. Terjemahan Khamami Zada. Jakarta: Prakarsa. 1975.

Jawa Pos edisi 14 Maret 2004.

Kompas, 22 Mei 2012. "Kebebasan Dimanipulasi".

Kompas, 24 Mei 2012. "Intoleransi jadi Sorotan dunia”. Halaman 9.

Latif, Yudi, dkk. Bayang-Bayang Fanatisme: EsaiEsai Untuk Mengenang Nurcholish Madjid. Jakarta: PSIK Universitas Paramadina. 2007.

Latif, Yudi. NEGARA PARIPURNA: Historisitas, Rasionalitas, dan Aktualitas Pancasila. Jakarta: PT. Gramedia. 2011.

Madjid, Nurcholish "Asas-Asas Pluralisme dan Toleransi Dalam Masyarakat Madani, dalam Abuddin Nata, dkk (ed), Problematika Politik Islam di Indonesia. Jakarta: UIN Jakarta Press. 2002.

Marianto, M. Dwi "Belajar Dari Alam dan Orang Desa”, Kompas, 28 April 2014, hal. 7.

Muchsin, M. Bashori. "Doktrin Cinta Kenabian”. Jawa Pos. 9 Agustus 2011. Hal. 4.

Mulkhan, Abdul Munir. Kesalehan Multikultural: BerIslam Secara Autentik Kontekstual di Aras Peradaban Global. Jakarta: PSAP Muhammadiyah. 2005.

Munjid, Achmad. "Pengajaran Agama Interreligius". Kompas. 4 januari 2014. Hal.7.

Nafis, Muhammad Wahyuni, dkk. KESAKSLAN INTELEKTUAL: Mengiringi Kepergian Sang Guru Bangsa. Jakarta: Paramadina. 2005.

Nordholt, Henk Schulte. Kriminalitas, modernitas dan identitas : dalam sejarah Indonesia. Yogyakarta: Pustaka Pelajar. 2002.

Rakhmat, Jalaluddin. Islam dan Pluralisme: Akblaq Alquran Menyikapi perbedaan. Jakarta: Serambi. 2006.

Siradj, Said Aqil "Mengurai kekusutan Keberagamaan”, Jawapos. 26 Januari 2012, hal 4.

Subkhan, Imam. Hiruk Pikuk Wacana Pluralisme Di Yogya. Yogyakarta: Kanisius. 2007. 
Ujan, Andre Ata, dkk. MULTIKULTURALISME: Belajar Hidup Bersama Dalam Pebedaan. Jakarta: PT Index. 2011.
Wahid, Aba Du. Ahmad Wabib: Pergulatan Doketrin dan Realitas Sosial. Yogyakarta: Resist Book. 2004.

Wahid, Abdurrahman. Tuban Tidak Perlu Dibela. Yogyakarta: LKIS. 1999. 